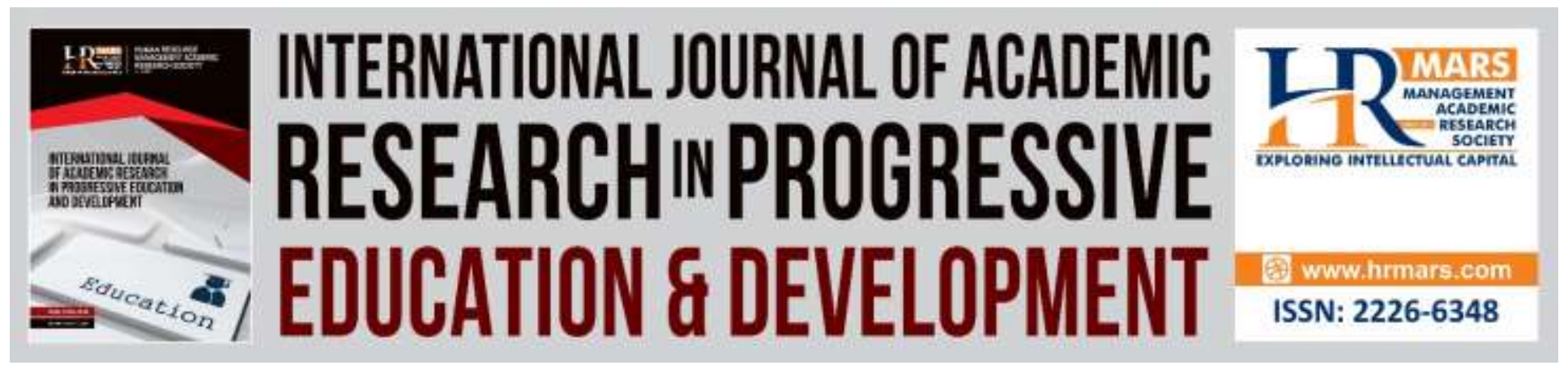

\title{
Mediation Effect of Reasoning Personality in the Relationship between Islamic Education Infusion Learning and Higher Order Thinking Skill
}

Tajul Rosli Bin Shuib, Mohd Razimi Husin, Nor Hasnida Che Md Ghazali

To Link this Article: http://dx.doi.org/10.6007/IJARPED/v8-i4/6911

DOI:10.6007/IJARPED/v8-i4/6911

Received: 18 October 2019, Revised: 22 November 2019, Accepted: 11 December 2019

Published Online: 30 December 2019

In-Text Citation: (Shuib et al., 2019)

To Cite this Article: Shuib, T. R. Bin, Husin, M. R., \& Ghazali, N. H. C. M. (2019). Mediation Effect of Reasoning Personality in the Relationship between Islamic Education Infusion Learning and Higher Order Thinking Skill. International Journal of Academic Research in Progressive Education and Development, 8(4), 1110-1119.

Copyright: (C) 2019 The Author(s)

Published by Human Resource Management Academic Research Society (www.hrmars.com)

This article is published under the Creative Commons Attribution (CC BY 4.0) license. Anyone may reproduce, distribute, translate and create derivative works of this article (for both commercial and non-commercial purposes), subject to full attribution to the original publication and authors. The full terms of this license may be seen

at: http://creativecommons.org/licences/by/4.0/legalcode

Vol. 8(4) 2019, Pg. 1110 - 1119

http://hrmars.com/index.php/pages/detail/IJARPED

JOURNAL HOMEPAGE

Full Terms \& Conditions of access and use can be found at http://hrmars.com/index.php/pages/detail/publication-ethics 


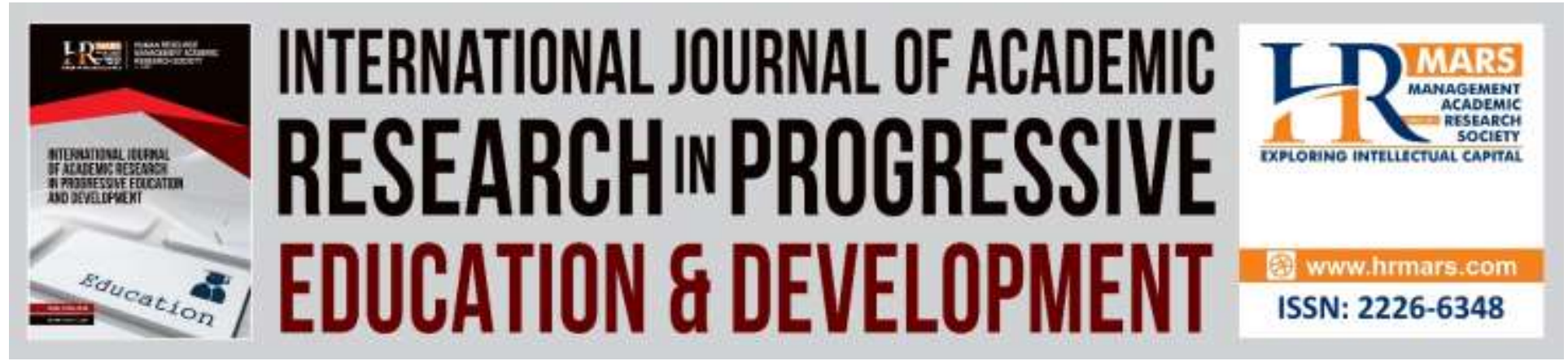

\title{
Mediation Effect of Reasoning Personality in the Relationship between Islamic Education Infusion Learning and Higher Order Thinking Skill
}

\author{
Tajul Rosli bin Shuib \\ SMK Sungai Manik, Perak. \\ Email: tajul_roslie@yahoo.com \\ Mohd Razimi Husin, Ph.D, Nor Hasnida Che Md Ghazali, Ph.D \\ Universiti Pendidikan Sultan Idris \\ Email: razimi@fpm.upsi.edu.my, hasnida@fpm.upsi.edu.my
}

\begin{abstract}
The main purpose of this research is to examine reasoning personality as a mediator in the relationship of Infusion Learning in Islamic Education (IEIL) and Higher Order Thinking Skill (HOTS). This research is based on Swartz, Fischer and Parks (1999) Infusion Learning Model. A model was developed to analyse mediation effect of Reasoning Personality on IEIL-HOTS relationship. This model examined IEIL as a single construct. Interrelation between variables was validated in the first place, so that the mediation effects test could be done. This quantitative survey research was conducted with random cluster sampling technique. There were 388 respondents involved in this study from 18,137 population. Data were analysed using path analysis, Structural Equation Modelling (SEM). This research discovered that there is significant inter-relationship between three variables. Thus, the Reasoning Personality became complete mediator in the relationship of exogenous variable IEIL and endogenous variable HOTS. In conclusion, the research model fit the expected results. Hopefully there will be more research on reasoning personality in the future.
\end{abstract}

Keywords: Islamic Education, Infusion Learning, Higher, Order Thinking Skills (HOTS).

\section{Introduction}

Stated in the Islamic Education Philosophy (FPI) that students are raised to become good Muslim through the formal learning environment in school. However, it does not mention about the need for soft skills so that students can compete in the working market either professional, partial professional or practical (Rahim, 2001) after graduation. To have this, students should have a set of quality thinking skills including emotional intelligence, self-management, problem solving, 
creativity and so on (Rajendran, 2013). Ministry of Education Malaysia (MOE) started to take the initiative to empower students' thinking ability in the school curriculum since the early 90s with infusion learning through the Primary/Secondary School Integrated Curriculum (KBSR/M) that practices Creative and Critical Thinking Skills (KBKK) across the curriculum. Nowadays, KBSM/KBSR is improved with the new Secondary School Standard Curriculum (KSSM) with a greater emphasis on High Level Thinking Skills (KBAT) and continuous student assessment in the classroom. Thus it reduces the exam-oriented base in school learning system (Curriculum Development Section, 2016).

There were curriculum and teaching specialists from within and outside the country have been appointed to develop approaches, strategies, methods and techniques for implementing the infusion learning in Malaysia (Rajendran, 2013). In terms of implementation, teachers face variety of difficulties to vary each approach in order to meet the needs of the current education including affecting students' cognitive, affective and psychomotor aspects (Audrey, 2010). Many forms of student centered activities that may promote cooperation, leadership and speech (Mel, 2010) are suggested for teachers and students' practice in classes. Even though the student centered strategy sounds better to encourage thinking skills, most of teachers are proven more comfortable to practice conventional teaching strategies frequently (Rajendran, 2013; Azmi and Halim, 2007) as they are easier in terms of time and class control. That is not a big issue since these conventional strategies are very important in the teaching of most of the Islamic Education syllabus with in depth discussion especially deep learning (Marton \& Saljo, 2005).

To encourage students' abilities to think, teachers have to understand the basic thought of their students. This reasoning personality somehow affect their higher order thinking ability (Ab. Halim et al., 2004). Students' thought are shaped by their surrounding (Fisher, 2009). So, this is the most basic thing that teachers must pay attention to. That is why teachers play one another role to students and that is sosialisation agent (Rosnani, 2012). Unlike the formal learning in class to promote HOTS, this requires more like informal extra time with students, especially involving after-school activities. In Science and Mathematics subjects, normally this basic guide is usually named as Scientific Reasoning Skills using certain measurement like Lawson Scientific Reasoning checklist (Rajendran, 2013). If students have good score and strong indication in this measurement, then they have strong tendency to perform better in thinking skills (Audrey, 2010).

\section{Statement of Problem}

While Malaysia has been practicing infusion learning to promote HOTS, Rosnani (2014) found that students' thinking skills are still insufficient. Both teachers and students could be the main factors. For example, Rajendran (2013) discovered that there are still less skilled teachers to practice the correct questioning techniques in the classroom. This was supported by Seman (2005) and Waheedawati (2003), which found that teachers are only using low level question while in the two-way interaction that did not work well while it is the most important element in empowering good thinking skills. Learning how to think should go with an effective questioning (dialogue). In addition, Brookfields (2015) added that teachers often ignore the HOTS-modelling when they implement the curriculum inflections and thinking skills in the classroom. Teachers 
should be an expert thinkers to show and model how to think and speak out systematically and critically. Unfortunately this does not happen in the way it should be Suhaimi (2014).

However, teachers also might face difficulties to understand their students reasoning personalities. This affects strategies to be implemented in their class. Students will not able to learn how think of they are shaped to negative and unhealthy way of thinking. This determine how they think about this world and affect the way they make decision now and in the future (Ellen, 2014). In this study it is called Reasoning Personality; the basic daily reasoning comes from their environment. For example, if they are shaped to think negative about A person, then there will be always negative decision for that $A$ person while there would be another thing to consider. Students must be understood personally and socially other than formal interaction in classroom. Since studies about reasoning personalities (Scientific Reasoning Skills) in Social Science are still lacking, it should be enriched to assist teachers to understand better the situation of their students and to determine the best way to socialize with their students inside and outside class. Teachers may reshape students' social personality in order to reshape their reasoning personality.

\section{Research Objectives}

The main objective of this study is to identify whether or not there is a significant mediation effect of Reasoning Personality in the relationship of Infusion Reasoning and HOTS. This is important to understand the role of the personality to enhance students thinking skills.

\section{Study Hypotheses}

$$
\begin{array}{ll}
\mathrm{H}_{\mathrm{a}}{ }^{01} & \text { Reasoning Personality is a significant mediator in the relation of Islamic Education } \\
\text { Infusion Learning (IEIL) and Higher Order Thinking Skills. }
\end{array}
$$

\section{Research Methodology}

This is a survey quantitative research. Data were collected with questionnaire. All constructs have been tested for their validity and reliability. Reasoning Personality construct is based on M. Neil and Stuart's (2007) list while IEIL construct is based on some previous references (Rajendran, 2008; Mayer et al., 2009; Braun et al., 2015; and Fisher, 2007). Higher order thinking skills instruments were adapted from the Rosnani (2014) and Rajendran's research instrument (2008). There were 388 respondents involved in this study from 18,137 population using purposive and random sampling technique. To test the hypotheses, data were analysed using path analysis, Structural Equation Modeling (SEM). 


\section{Findings}

Mediation effect of Reasoning Personality in the relationship of Islamic Education Infusion Learning and Higher Order Thinking Skills.

Based on path analysis (SEM) using AMOS 4.0, Reasoning Personality completely mediates the relation of Islamic Education Infusion Learning and Higher Order Thinking Skills. Thus it met Baron and Kenney's (1986) requirements to test mediation effects. Variables should have significant interrelationship between one to another; IEIL should give significant effect to Reasoning Personality and HOTS. Reasoning Personality also must has significant effect to HOTS. Basically, IEIL was proven to give significant direct effect to Higher Order Thinking Skills (beta=0.864) as shown in figure 6.1. After the mediator variable Reasoning Personality came into the model, the beta coefficient value for IEIL reduced. In other word the direct effect IEIL to HOTS will reduce as the mediator entered the model. The result shows that beta coefficient value in the relation of IEIL and HOTS was reduced from 0.864 to 0.155 .

\section{Step 1: Direct effect.}

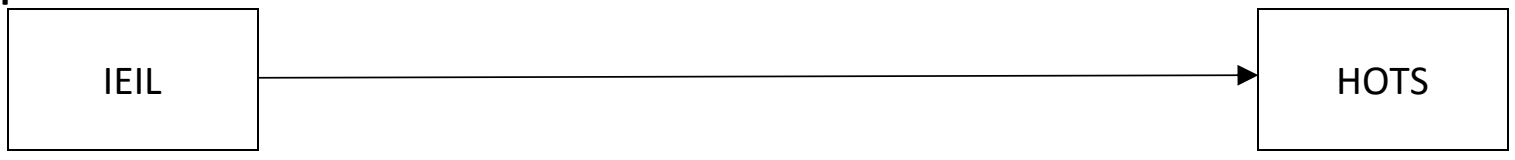

\begin{tabular}{|ll|l|}
\hline $\begin{array}{l}\text { Islamic Education Infusion } \\
\text { Learning (IEIL) }\end{array} \quad \begin{array}{l}\text { Higher Order Thinking Skills } \\
\text { (HOTS) }\end{array}$ & $0.864^{* * *}$ \\
\hline
\end{tabular}

\section{Step 2: Indirect Effect}

Step 3: Indirect Effect

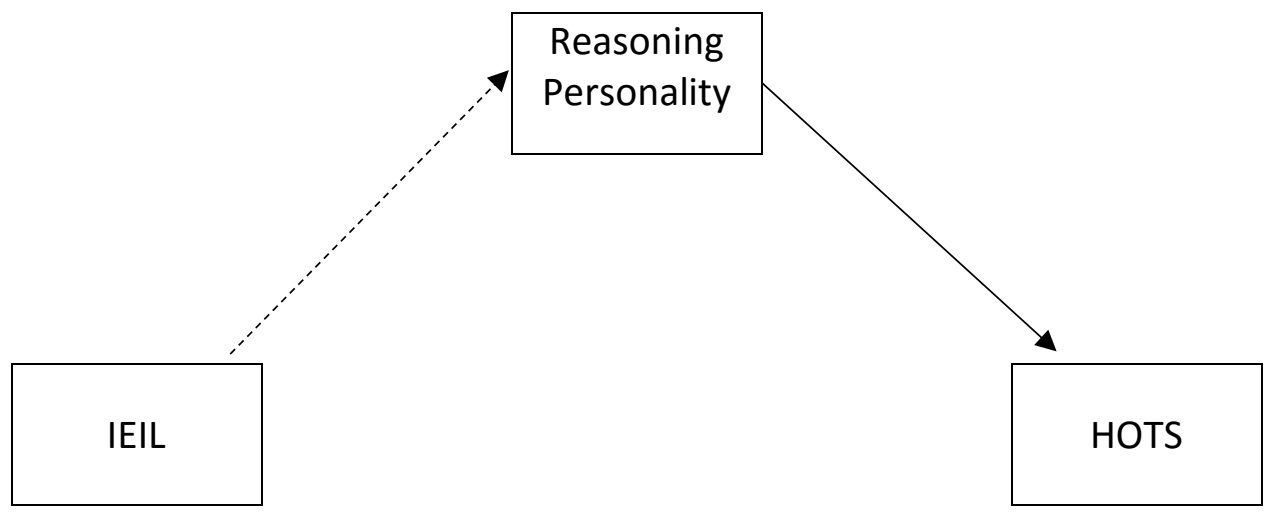

\begin{tabular}{|c|c|c|}
\hline Islamic Education Infus & Reasoning Personality & $0.975 * * *$ \\
\hline Reasoning Personality & Higher Order Thinking Skills & $0.815^{* * *}$ \\
\hline
\end{tabular}




\section{Step 4: Complete mediation}

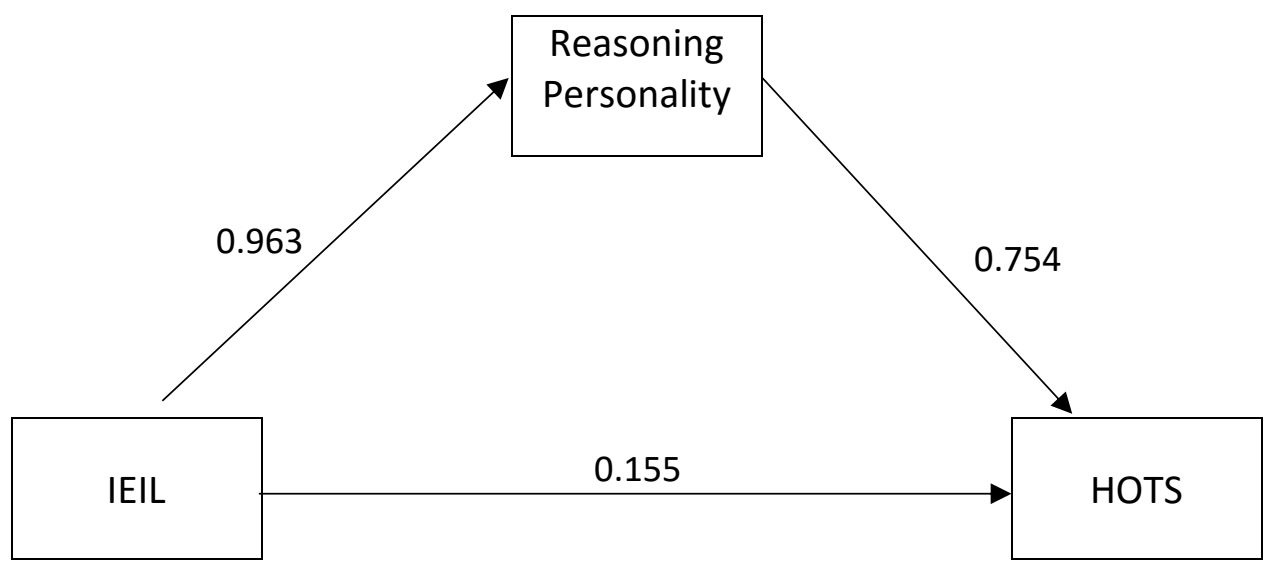

1) Indirect Effect $=0.963 \times 0.754=0.726$

2) Direct Effect $=0.155$

3) Both indirect effects (IEIL to Reasoning Personality and Reasoning Personality to HOTS) are significant.

4) Oleh kerana, Kesan Tidak Langsung > Kesan Secara Langsung, pengantara berlaku

5) Jenis pengantaraan di sini adalah Pengantaraan Lengkap kerana Kesan Secara Langsung tidak signifikan selepas konstruk pengantara memasuki model

\begin{tabular}{|lll|l|}
\hline $\begin{array}{l}\text { Islamic Education Infusion } \\
\text { Learning (IEIL) }\end{array}$ & $\begin{array}{l}\text { Reasoning Personality } \\
\text { Reasoning Personality }\end{array}$ & $0.963^{* * *}$ \\
$\begin{array}{l}\text { Islamic Education Infusion } \\
\text { Learning (IEIL) }\end{array}$ & $\begin{array}{l}\text { Higher Order Thinking Skills } \\
\text { (HOTS) }\end{array}$ & $0.754^{* * *}$ \\
\hline
\end{tabular}

Figure 6.1. The role of Reasoning Personality as a Mediator in the IEIL-HOTS relationship.

Table 6.1 shows the "Standardized Regression Weights" to measure the effect of IEIL to HOTS as 0.081, while the "Standardized Regression Weights" for IEIL to Reasoning Personality is 0.580. This model shows all "fitness indexes" are satisfactorily met. Even though the GFI is less than 0.9, however it is still acceptable (Baumgartner and Homburg, 1995). Thus, the structure model is considered reasonable and acceptable. "Fitness indexes" for the model is as shown on the table 6.1: 
INTERNATIONAL JOURNAL OF ACADEMIC RESEARCH IN PROGRESSIVE EDUCATION AND

DEVELOPMENT

Vol. 8, No. 4, 2019, E-ISSN: 2226-6348 @ 2019 HRMARS

Table 6.1. "Fitness Indexes" for the Model Structure

\begin{tabular}{lccc}
\hline \multicolumn{1}{c}{ Category name } & Name in index & Index & Note \\
\hline Absolute fit index & RMSEA & 0.060 & Meet the required level \\
& GFI & 0.808 & Meet the required level \\
Incremental fit index & CFI & 0.914 & Meet the required level \\
Parsimonious fit index & Cmin/ df & 2.410 & Meet the required level \\
\hline
\end{tabular}

\section{Discussion}

This study has shown the importance of Reasoning Personality to enhance students' thinking skills. Students are believed to have a clear thought and positive reasoning in their life as well as in academic discussion. This could be an opportunity for teachers to give great emphasis in affective aspect (rohani) in the classrooms other than cognitive and psychomotor. Besides, this scenario also indicates that students are able to learn contextually. Thus teachers must vary contextual learning environment to meet 21st century learning aspiration. It should be done continuously since personality is changeable especially when is related to youngsters. Other than that, this study also proved that there are good teachers' effort to have a good rapport to their students. It is because reasoning personality is more about socially-emotionally connection between people. In Islamic Education, this rapport plays importance role to shape students' spiritual identity. Reasoning personality role as mediator can be tested to other models with another elements of Infusion Learning.

Result of this study supported Primi, Morsanyi and Chiesi (2014) and Gerber, Marek (2001) who discovered that scientific reasoning skills (reasoning personality) variable as a significant mediator in the relation of students' learning and their academic performance. Even though those studies were in Science and Mathematics perspectives, it depicted the same scenario to explain the strong interrelation between discussed variables. The significance of reasoning personality was also explained by Hassan, Eizuan, Shah \& Uzi (2012) with extended research to prove the effect on students' thinking ability provided that the infusion learning is practiced continuously in an systematic order. These studies also show us that the reasoning personality is discussed globally to ensure that our young generation live in healthy mental-reasoning environment.

State Education Department and teachers should collaborate together to cope with reasoning personality issue. Teachers are encouraged to prepare comprehensive modules which include reasoning personality to their assessments. This is to make sure that all teachers have a standard focus and strategies to approach students in order to get them closer to Islamic thinking. This will help them to understand Islam better and become good Muslims as Malaysia future leaders. Other than that, students will be able to learn Islamic Education willingly without the feeling of coercion since learning will only be effective when students learn Islamic Education willingly and sincerely. 


\section{Conclusion}

The result of this study has met the research expectation. Reasoning personality plays its significant roles to support students thinking skills development. Further research on reasoning personality should be done widely especially in Islamic Education perspective since it is still lacking. Hopefully this study could provide some ideas to teachers and education administrators in Malaysia to pay better attention to students' reasoning health. Teachers will be a good socialization agent if they understand their students socially instead of just academically.

\section{References}

Tamuri, A. H., Yusop, A., Osman, K., Awaluddin, S., Rahim, Z. A., \& Razak, K. A. (2004). Keberkesanan P \& P Pendidikan Islam Ke Atas Pembangunan Diri Pelajar. Laporan Penyelidikan Fakulti Pendidikan, Ukm Dan Jabatan Pendidikan Islam Ddan Moral (japim), kpm.

Tamuri, A. H., Mahmud, Z., \& Bari, S. (2005). Permasalahan Pelajar-Pelajar Fakir Miskin Di Daerah Sabak Bernam. Jurnal Pendidikan, 30, 21-33.

Rashid, A. R. A. (2001). Nilai-nilai Murni Dalam Pendidikan: Menghadapi Perubahan Dan Cabaran Alaf Baru. Kuala Lumpur: Utusan Publications and Distributions.

Ainon \& Abdullah, Hassan. (2005). Pemikiran Reka Cipta: Kaedah Mengajar Dan Bahan Latihan Untuk Guru Dan Jurulatih. Pahang: Pts Publications and Distributions SDN BHD.

Anderson, Lorin, W., David, R. Krathwohl, and Bloom, B. S. (2001). A Taxonomy for

Learning, Teaching, and Assessing: A Revision of Bloom's Taxonomy of Educational Objectives. Allyn \& Bacon.

Osler, A. (2010). Students' perspectives on schooling. Open university press. Mcgraw hill.

Bahagian pembangunan kurikulum. 2016. Dokumen standard kurikulum dan pentaksiran pendidikan islam. Putrajaya: kementerian pendidikan.

Braun, J. D., strunk, D. R., Sasso, K. E., \& Cooper, A. A. (2015). Therapist use of socratic questioning predicts session- to-session symptom change in cognitive therapy for depression. Behaviour research and therapy, 70, 32-37.

Brookfields, S. (2005). The power of critical theory for adult learning and teaching. The adult learner, 85.

Coombs, B. (2009). Mengajar secara efektif. (terjemahan: siti aishah mohd elias). Kuala lumpur: institut terjemahan negara malaysia.

Jeffrey, B., \& Woods, P. (2009). Creative learning in the Primary School. New York: Routledge.

De Bono, Edward. (2000). Six thinking hats. London: penguin books.

De Bono, Edward. (2015). Serious creativity: how to be creative under pressure and turn ideas into action. New: york: random house.

Lambert, E. R. (2014). The power of creative thinking. Kuala lumpur: ylp publication.

Fisher, R. (2007). Dialogic teaching: developing thinking and metacognition through philosophical discussion. Early child development and care, 177(6-7), 615-631.

Fisher, Robert. (2009). Creative dialogue: talk for thinking in the classroom. New york: routledge. Hussin, H. (2012). Worldview dan amalan: pengalaman kadazan dataran penampang sabah. Borneo research journal, university of malaya, 1(1). 
Howard Kahane Dan Nancy Cavender. (2006). Logic and contemporary rhetoric: the use of reason in everyday life. Australia: thomson wadsworth.

Sidi, J. (2011). Remaja kreatif luar biasa. Selangor: millenia.

Kamarul, A. J., \& Ab Halim, T. (2007). Pendidikan islam: kaedah pengajaran dan pembelajaran. Johor: universiti teknologi malaysia.

Kanazawa, T., Satoshi., \& Norman, li. (2015). Happiness in modern society: why intelligence and ethnic composition matter. Journal of research in personality, 59(4), 111-120.

Marton, F., \& Saljo, R. (2005). Approaches to learning in f. Marton, d. Hounsell \& nj entwistle. The experience of learning: implications for teaching and studying in higher education. 3rd (internet) edition.

Mayer, R. E., Stull, A., Deleeuw, K., Almeroth, K., Bimber, B., Chun, D., \& Zhang, H. (2009). Clickers in college classrooms: fostering learning with questioning methods in large lecture classes. Contemporary educational psychology, 34(1), 51-57.

Silberman, M. (2010). Pembelajaran aktif: 101 strategi untuk mengajar apa jua subjek. (terjemahan: zainab ahmad). Kuala lumpur: institut terjemahan negara malaysia.

Nawi, N. H. M. (2011). Pengajaran dan pembelajaran: penelitian semula konsep-konsep asas menurut perspektif gagasan islamisasi ilmu moden.

Rajendran, N. (2008). Teaching higher order thinking skills in language classrooms: the need for transformation of teaching practice. Tidak diterbitkan. Disertasi kedoktoran. Michigan state university, east lansing. Usa.

Rajendran, N. (2013). Teaching and acquiring higher order thinking skills: theory and practice. Tanjung malim: penerbit universiti pendidikan sultan idris.

Paul, R., \& Elder, L. (2006). Critical thinking: learn the tools the best thinkers use. Ohio: pearson prentice hall.

Robert, F. (2009). Creative dialogue: talk for thinking in the classroom. New york: routledge.

Rohani, A. \& Nordin, A. R. (2010). Hubungan guru-pelajar dan kaitannya dengan komitmen belajar pelajar: adakah guru berkualiti menghasilkan perbezaan? Jurnal pendidikan malaysia, 35(2), 61-69.

Rosnaini, S., Maimun, A., \& Mok, S. S. (2011). Siri kemahiran generik: kemahiran berfikir. Selangor: penerbitan multimedia sdn bhd.

Rosnani, H. (2003). Malaysian teachers' attitudes, competency and practices in the teaching of thinking. Intellectual discourse, 11(1).

Hashim, R. (2012). Memenuhi aspirasi kemahiran berfikir dalam pelan pembangunan pendidikan malaysia 2013-2025 menerusi inkuiri dan pedagogi filosofiyyah dalam kalangan guru. Persidangan majlis dekan fakulti pendidikan, universiti teknologi malaysia.

Seman, S. (2005). Interaksi lisan dalam pengajaran dan pembelajaran komponen kesusasteraan melayu (komsas) dalam mata pelajaran bahasa melayu.tesis doktor falsafah. Fakulti pendidikan, universiti kebangsaan malaysia, bangi.

Stephen, R. C. (2013). The seven habits of highly effective people. United kingdom: simon \& schuster uk limited. 
Taat, S. (2011). Gaya pertautan dan motivasi pelajar, serta pengajaran dan bimbingan guru pendidikan islam terhadap pembelajaran terarah kendiri (ptk) pelajar. Tesis phd. Universiti malaysia sabah.

Swartz, R., Fischer, S., \& Parks, S. (1998). Infusing the teaching of critical thinking and creative thinking into secondary science: a lesson design handbook: critical thinking books and software. Ca: pacific grove.

Tegin, J., Ekvall, S., Kragic, D., Wikander, J., \& Iliev, B. (2009). Demonstration-based learning and control for automatic grasping. Intelligent service robotics, 2(1), 23-30.

Waheedawati, W. (2003). Penggunaan penyoalan lisan dalam kalangan guru sejarah di sekitar bandar sibu. Kertas projek sarjana pendidikan. Fakulti pendidikan, universiti kebangsaan malaysia, bangi. 